\title{
Grab That Mike: Communicative Issues in French Talk Show
}

\author{
("Grab That Mike": Questões Comunicativas em um "Talk Show" Francês)
}

\author{
Ludwina VAN Son \\ (University of Antwerp UFSIA)
}

\begin{abstract}
In this analysis we have chosen a recent French talk show to illustrate how communication is turned into some new kind of "ideology"nowadays: in other words, you have to communicate if you consider yourself a citizen of today's world. The main characteristic of issue-centered talk shows being the destabilization of the implicit rules and participation framework, we observe how the so-called democratic right to express ourselves is (mis) used by the talk show host to secure the dynamics of the show. In order to reveal the host's manipulations, we have examined the verbal interactions between host and guests on the following issues: topic choice, turn-taking mechanisms and identity construction of the talk show's guests. In the perspective that this kind of talk show presents itself as a public space where direct democracy can be exercised, the analysis of the discursive strategies of the talk show host reveals the impact of a mediatic participation framework. KEY-WORDs: French Television Talk Shows; Constraint of Communication; Forum; Discursive Strategies; Verbal Interaction; Topic Choice; Turn Taking; Identity Construction.
\end{abstract}

REsumo: Para a presente análise escolbemos um "talk show" francês recente para ilustrar como a comunicação se transforma em um novo tipo de ideologia: em outras palavras, você deve se comunicar se você se considera um cidadão do mundo de hoje. Sendo a principal característica do talk show a desestabilização das regras implícitas e o framework de participação, observamos como o tal direito democrático de expressão é interpretado pelo apresentador para manter a dinâmica do programa. Para revelar suas manipulações, examinamos as interações verbais entre apresentador e convidados nos seguintes temas: escolha do tópico, mecanismos de tomada de turno e construção de identidade dos convidados. É nessa perspectiva que este tipo de programa se apresenta como um espaço público onde a democracia direta pode ser exercitada; a análise das estratégias discursivas do apresentador do talk show revela o impacto de um framework de participação mediada.

PALAVRAS-CHAVE: "Talk show" da TV Francesa; Estratégias Discursivas; Interação Verbal; Escolha de Tópico; Tomada de Turno; Construção de Identidade. 


\section{Introduction}

In this last decade of the twenthieth century, Western society appears to have lost the belief that ideas can govern the world. Today we find ourselves living in a postmodern world ${ }^{1}$ that no longer accepts dominant ideological grounds and puts forward eclectism. Nevertheless a new kind of "ideology" seems to be emerging and television makes a major contribution in spreading it. Its key word is "communication" or more specific, the obligation to communicate. In other words, you have to communicate if you consider yourself a citizen of today's world ${ }^{2}$.

\section{Express yourself}

Several reasons could be invoked for treating French television talk shows in a perspective that seeks to investigate the relation between discourse and society. The most obvious and trivial ones are that verbal exchange is at the heart of these broadcasts and that French society is known to be very talkative and highly appreciative of rhetorical capacities. A more fundamental motive however for taking the option of discussing talk shows is that these "spectacles de paroles" elaborate some kind of statement on how communication is to be perceived. They illustrate an idea that not only is quite strong but that is also imposing itself as a system: the necessity of expression for all and by all. Expressing yourself is necessary and refraining from it is wrong; you bave to express yourself : this is a principle on which talk shows endlessly insist ${ }^{3}$. A very democratic

\footnotetext{
J.-F. Lyotard (1986) defines post modernity as the bankruptcy of the "great stories": communism, capitalism, christiansim, etc.

2 To the sociologist D. Wolton the link between communication and democratic society is obvious since they both belong to the same set of values.

3 Bertrand Poirot-Delpech, distinguished member of the Académie française, formulates it as following: "L'audiovisuel et ses recettes d'audience régissent peu à peu tous les comportements de la vie en société. La notoriété remplace le savoir, et la jactance le discours articulé. Hier condition et prestige de la méditation, le silence est devenu synonyme de panne, de trou. Meubler, enchaîner, tenir le crachoir et l'antenne: telle est la morale nouvelle, avec reporters et animateurs pour hérauts. Témoin la vogue de ce qui coûte le moins cher à produire: le talk-show. Il est désormais habituel que les chaînes généralistes, sans parler des thématiques, soient toutes en train d'empêcher une brochette d'invités de se voler la parole. "Laissez-moi finir", "je ne vous ai pas interrompu" sont les énoncés les plus fréquents, quel que soit le sujet à l'affiche ..." ("Il faut qu'on parle!" in Le Monde, 19/6/01)
} 
principle at first sight, but what happens if this so-called democratic right is turned into an obligation? What if this idea of free speech by and for all needs to go through a televisual casting-mould? After all, television has its own rules and programmes have their proper format. The mediatic apparatus taken into account, talk shows will reveal themselves incapable of realizing their communicative ambitions. In the end, putting on a good show appears to be incompatible with the ideology ${ }^{4}$ of expression television itself is spreading.

When communication is considered as compulsory in a mediatic environment, it also heavily compromises the identity construction of the talk show guest both as a communicating individual and as a citizen involved in the self-proclaimed process of democratic participation. We will address this issue by analising some sequences of a corpus of French talk shows that present themselves as debates on social matters. In particular we will focus on the discursive strategies of the talk show host (turn-taking mechanisms, terms of address, taxemic markers) that reveal the impact of a mediatic participation framework ${ }^{5}$.

\section{The perfect host}

We would like to illustrate this with some examples drawn from one of the latest series of French talk shows entitled $D u$ fer dans les épinards (Iron in the Spinach).

According to Timberg (1994: 274), the genre of talk shows refers to at least two types: the personality-centered shows and the more issuecentered ones. In the first category we observe primarily dyads about

\footnotetext{
4 "Ideology" taken in the sense of Hodge \& Kress, Language as Ideology (1993: 6): "a systematic body of ideas, organised from a particular point of view". This new "ideology" of communication in today's society is indeed primarily carried out by television: Cf. "Le message principal - sinon l'unique message - que la télévision véhicule aujourd'hui est l'importance de la communication comme nouvelle valeur centrale autour de laquelle la société tout entière est censée s'organiser. Le message prend de plus en plus une forme performative: le son permanent et les images de la télévision nous disent en résumé une seule chose: il faut communiquer, quel que soit le contenu" (Breton \& Proulx, 1990: 35)

5 The notion of participation framework has been extensively elaborated by E. Goffman (1981). However, we will limit our analysis to identity construction in order to not exceed the boundaries of this article.
} 
more personal and noncontroversial topics; the latter displays a kind of group discussion about topics that are socially oriented and often controversial. Du fer dans les épinards clearly belongs to the second type.

As in most French talk shows, the programme announces itself as a socio-cultural debate. Its host, Christophe Dechavanne, is quite a celebrity in media business. He started his television career as a weatherperson but soon he was offered the chance to host two afternoon shows that were a mix of entertainment and celebrity interviews. The real breakthrough however came with $\mathrm{Ciel}$, mon mardi! ${ }^{6}$, a provocative late night show that in no time became the talk of the town. Over the last years, Dechavanne did two talk shows, of which one is Du fer dans les épinards and at the present time he is back on television with another edition of Ciel, mon mardi!. Constantly displaying a mixture of seriousness and irony, Dechavanne is perhaps the most representative of French talk show hosts: if destabilization is a prime characteristic of the genre ${ }^{7}$, his playful ambiguity should be considered a major contribution to the success of the formula. We will see at different occasions how Dechavanne goes about creating this destabilization by manipulating the so-called ideology of expression.

\section{Show time}

The numerous participants (an average of 25) of Du fer dans les épinards are seated in an amphitheatre amongst the studio audience. In front of them, in the lower part of the semicircular auditorium, stands the host responsible for organizing the debate and keeping it going. Dechavanne is playing his part in his usual offhand manner, offering something with one hand taking it back with the other. Although he clearly seems to be heading for a more adult and "responsible" television, we still remain in this no man's land of journalistic deontology, favourite playground of his, master of derision, who does certainly not forget that a talk show is first of all a show.

\footnotetext{
6 Translated, this would sound like "Good heavens, there goes Tuesday!".

7 Cf. Penz (1996: 56) who, on base of an empiric analysis of discursive strategies within american talk shows, distinguishes destabilization or undecidability as a prime characteristic of the genre.
} 


\section{Let's talk about ...}

The formula of the show is quite simple. The show begins, the host appears on the set, welcoming the viewers and his guests, recalling the series to which the show belongs as well as its number ("du fer dans les épinards numéro vingt-cinq") and announcing the theme ${ }^{8}$ of the debate in the following way:

(1) ce soir nous allons parler de

(2) alors on va parler ce soir

tonight we're going to talk about

As the "cliché" of the title, "iron in the spinach" indicates, the show is based on the discussion of "idées reçues". Once the theme is announced, a sort of a sketch by the host follows delivering a mixture of "idées reçues" and points of view.

After the theme has been announced, a certain vagueness regarding the thematic delimitation remains, as the following example from the broadcast on dogs shows:

(3) ça va être un petit peu le thème de ce soir this will be somewhat tonight's topic

If the dogs are only "somewhat" the theme of the debate, it seems possible or even legitimate to raise other matters of discussion ${ }^{10}$. But

\footnotetext{
8 The issue of "topic choice" is essential. According to C. Ilie (1999), interaction dynamics in talk shows are partly rule-governed and topic-centered (i.e. based on rules and respecting a prefixed list of possible topics treated) but rely, at the same time, on conversational discourse practices that allow a less rigid turn taking system.

9 As Bourdieu puts it, these "idées reçues" do not need active reception since they have already been received. This element again confirms the communication constraint within talk shows: "l'échange de lieux communs est une communication sans autre contenu que le fait même de la communication" (1996: 31).

10 Topics treated during interaction are to be considered taxemic markers. Not only does a topic have a structuring function (C. Kerbrat-Orecchioni 1992), as it has to be inevitably introduced by someone at some stage of the interaction, it is also operating on a taxemic level by its proper content. After all, some topics are more favorable to an interactant than others, he (or she) feels more involved by a topic than another or the topic brought on relates to his personal field of competence. Enough reasons for a participant to try to introduce a topic that empowers him to occupy a dominant position during the interaction.
} 
such thematic excursions inevitably lead to the "don't talk about this, talk about that" game that Dechavanne manages in his typical way and that gives him the opportunity to sanction severely the participants wandering off the right track. Thematic vagueness proves to be very rewarding because sanctioning is part of the show. The host of the talk show knows that the audience is watching not only for the debate but also for the damage it provokes.

\section{A television forum}

One term that keeps coming back in the strictly codified opening sequence and that can be considered as a generic autodefinition is the word " forum".

(4) bienvenus pour ce huitième forum du fer dans les épinards c'est un forum vous aurez tous la parole

welcome to this eighth forum of iron in the spinach it's a forum you will all have the opportunity to speak

(5) ravi de vous recevoir pour ce forum alors qui dit forum dit évidemment la possibilité pour chacun de s'exprimer d'avoir des choses à dire

delighted to have you here for this forum now the term forum implies of course that each and everyone has the possibility to express themselves to have some things to say

This label allows the talk show to link with the long and respectable tradition of the "agora". Dechavanne redefines the word into its television version: "forum" means "the opportunity for each and everyone to express themselves". Whereas in the ancient tradition, doing and talking went hand in hand because talking of public affairs implies coming to certain decisions that are not free from consequences, the television form stresses talking only. This means we are here to talk and if this is to be considered a privilege it is also a constraint because one cannot join the set without talking, one's presence is not meant to be silent. This constraint leads to a struggle for "the floor" 11 , a struggle that if it does not arise spontaneously, is provoked by the host. If we consider the viewing ratings, this struggle is as important as the subjects to be discussed.

11 For an extensive review of the theory of turn taking mechanisms, see C. Kerbrat-Orecchioni (1990: 159-192). 
(6) je ne viens pas vous chercher les uns ou les autres n'hésitez pas à lever la main pour vous exprimer hein

I won't come and invite anyone don't hesitate to raise your hand to express yourself right

\section{Join the party}

At the beginning, everything goes well. We are here to express ourselves, so let's go for it. No wonder one can observe a quasi synonymy of the verbs "exprimer" (express), "participer" (participate) and "intervenir" (intervene). Whoever intervenes, is expressing himself and thus participating. To talk is to participate and we are trapped into something that at looks like a huge celebration of free and generous verbal exchange.

(7) vous participerez quand vous voulez hein you can participate whenever you want right

(8) merci monsieur vous réintervenez quand vous voulez thank you sir you may intervene again whenever you want

(9) merci vous interviendrez quand vous voudrez tout au long de cette soirée thank you you can intervene whenever you want throughout the evening

(10) vous pouvez intervenir quand vous voudrez you can intervene whenever you want

(11) vous interviendrez quand vous voudrez évidemment ça vaut pour tout le monde you can intervene whenever you want of course this applies to everybody

(12) vous interviendrez quand vous vous voudrez you can intervene whenever you want

(13) vous interviendrez ce soir quand vous voudrez n'est-ce pas you can intervene tonight whenever you want won't you

As a philanthropic host, Dechavanne also gives those who cannot express themselves elsewhere the chance of doing so, as the following example of the show on "techno" music reveals:

(14) ce sera donc la dernière émission de l'année et nous avons décidé de la consacrer à nos camarades jeunes qui ont parfois un peu de souci à s'exprimer à être libres à avoir la possibilité d'écouter ce qu'ils veulent dans les endroits qu'ils veulent et rassembler à peu près dans le nombre qu'ils veulent

this will be the last broadcast of the year and we've decided to devote it to our young friends who sometimes have difficulties expressing themselves to be free to bave the possibility to listen to what they want where they want and to get together in groups more or less as big as they want 
Another argument in favour of this freedom of expression is the liberty of the debater, whose utterances are not censored. On this set, everyone can say whatever he wants and whenever he wants to on the condition that he share it with others and accept that others do the same:

(15) un monsieur qui est venu ici dans ce plateau il fait bon il est libre aussi on est en démocratie a gentleman who has come on this set everything's fine he's also free this is democracy

(16) ah mais il va dire ce qu'il veut dire il est libre quand même hein il est libre ob but he can say whatever he wants he's free after all he's free

\section{Talk, don't talk}

Nevertheless, things are rapidly getting more complicated. If the host's task is to provide the floor to his guests, it is also his task to impose silence on those who talk too much or too long. Taking turns has to be monitored by the host, but it is indeed something difficult to regulate. Surrounded by numerous guests and knowing that a talk show without conflicts will not keep the viewers'attention, Dechavanne is handling the turn management with a certain duplicity, if not hypocrisy, since the turn taking rules that are constantly invoked are also constantly broken.

Two kind of figures can be isolated: one where the host encourages talking and the other where the host forbids it.

First figure:

(17) est-ce que c'est l'avis de cette jeune femme qui veut parler is this the opinion of the young woman who wants to talk

(18) jeune homme vous n'avez pas l'air d'être d'acord . non . vous ne voulez pas young man you don't seem to agree do you would you like to

(19) est-ce qu'il y a un adolescent un jeune qui veut parler à propos du respect dire quelque chose non

is there an adolescent a youngster who wants to talk about respect say something no

Second figure:

(20) arrêtez Albert posez le micro méchant stop it Albert put down the micro bad boy

(21) excusez-moi laissez-moi finir madame I'm sorry let me finish madam

(22) non non laissez enchaîner s'il vous plaît no no let me get on please

(23) allô les gars non arrêtez hi guys no stop it 
It's easy to understand why the two movements have to take place at the same time: making people talk is the same as imposing silence. The two are inevitably linked since it is the violence of the interruption ${ }^{12}$ that warrants the freedom of expression.

It is precisely at this point that the imperative of the constant and deontic expression reveals itself. One has to talk but it is this obligation (falloir) that leads to failure (faillite). Because of the obligation to talk for everyone, only very few succeed to do so. If all express themselves nothing can be heard and the debate turns into a circus. Hence, we could say that the debate of Dechavanne is at the same time an attempt to clarify some social issues and a "trick" shown to the audience.

\section{Talking together}

As in many political debates, democracy is invoked to set up an antidemocratic regime of, in this case, taking the floor. The "agora" turns into a boxing ring: I am the one talking and every one else should shut up. Of course the host is well aware of this, acting as if he is distressed but secretly congratulating himself on this outcome:

(24) ah non c'est pas la démocratie c'est le bordel maintenant attendez une seconde une seconde une seconde

ob no this is not democracy this is chaos now wait just a second just a second just a second

Pierre Bouteiller, a radio commentator, recently proposed a definition of the typical style of Dechavanne, formulating it as "l'autobordélisation pour shooter l'audimat" meaning "screwing things up to pump up the ratings". This formula probably applies to a lot of programs of the same genre. The media law necessarily conflicts with the democratic principles of the "talking together". If everybody has to have access to the floor, time has to be provided. But we all know television hasn't got time to spare. Is diminishing the number of participants a valuable alternative?

12 Contrary to classical rhetoric where the notion of "interruption" stands for self-interrupting ("l'auto-interruption", C. Kerbrat-Orecchioni 1990: 173), in conversation and discourse analysis "interruption" indicates the next speaker taking the turn when current speaker has not finished talking. 
It is not because not only would it break down the so-called democratic principle but it would also compromise the very purpose of the talk show: a large number of guests creates a better opportunity for conflicts. To put it a bit bluntly: discussing cannot work well in the presence of a camera when one pretends to inform but also wants to amuse.

In the next fragment the ambiguity we tried to reveal is clearly illustrated. Dechavanne is facing mister Truchot, spokesman of the tobacco industry that has come under serious attack:

(25) CD: monsieur Truchot soyez attentif parce que c'est vrai jusque-là vous $\mathrm{re}=$ vous représentez les cigarettiers jusque là pt ((geste bouche cousue $))$ on vous entend pas vous êtes extrêmement sage mais je vais vous donner la parole d'ici quelques instants parce que tout ce que vous entendez ici ce soir il va falloir que vous en débatouilliez d'ici quelques minutes si vous voulez bien monsieur Truchot

Mister Truchot pay attention now because it's true up till now you have represented the tobacco industry up till now ((mimes mouth shut)) we haven't heard you you are extremely well-behaved but I'm gonna give you your turn in a few moments because everything you have heard here tonight you will have to chat about in a few moments if you want to mister Truchot

JPT: mais jusque-là vous ne m'avez PAS donné la parole

but until now you have NOT given me my turn

$\mathrm{CD}$ : tout à fait mais vous êtes grand vous pouvez la prendre quand vous voulez monsieur Truchot c'est un endroit ici tout à fait démocratique

that's right but you're a grown up you can have it whenever you want mister Truchot this is a completely democratic place here

Three things can be noticed:

- the occurrence of "falloir" (you have to) reminding us that we are within the ideologic constraint of expression,

- the condescending effect of the slang term "débatouiller" (chat),

- and finally the double bind relation between host and guest. "I'm gonna give you your turn" says Dechavanne to Truchot but by saying this he is forbidding his guest to speak and Truchot is well aware of that: "you have NOT given me my turn".

We are facing here an absurd and contradictory situation in which the guest only succeeds in speaking by interrupting the host, who is precisely the one who should help him to get his turn. Pretending to look 
after the argumentative welfare of the tobacco spokesman, Dechavanne makes it impossible for him to talk by saying something like: "you can talk whenever you want ... but not now". This is quite a paradoxical injunction with undoubtable mediatic and telegenic effects. Poor $\mathrm{Mr}$ Truchot is perplexed and the audience is having a laugh. In these circumstances we need to look with irony at this other allusion to democracy, which closes the sequence.

Is this a democratic broadcast? We don't think so. After all, there's only one speaker having the full right to express himself and that is the host, verbalizing his privilege by playing the upper priest of the "cathodic mass".

\section{Who's talking?}

What preceeds could give the impression that getting the floor is the sole difficulty for the guests. Unfortunately, once the participants have gotten access to the floor, other obstacles are awaiting. Identity construction is another field Dechavanne likes to play in his ambiguous way. In this so-called democratic gathering of free speech, our host pretends to level with his guests in order to get their necessary contribution. In his attempt to act like just another participant of the show, the host usually is or offers to be called by his first name. A simple strategy commonly used in these kind of programmes that Dechavanne turns into another communication trap.

Following examples should shed a light on this:

(26) CD: bonsoir Sandra

good evening Sandra

S: bonjour bonne année

bello happy new year

CD: bonne année Sandra euh vous pareil euh habits de fête ce soir Sandra

Happy new year Sandra eub you too eub party outfit tonight Sandra

S: oui oui c'est une fête de venir à la télé

Yes yes getting on television is a special occasion

$\mathrm{CD}$ : c'est très gentil

That's very kind of you 


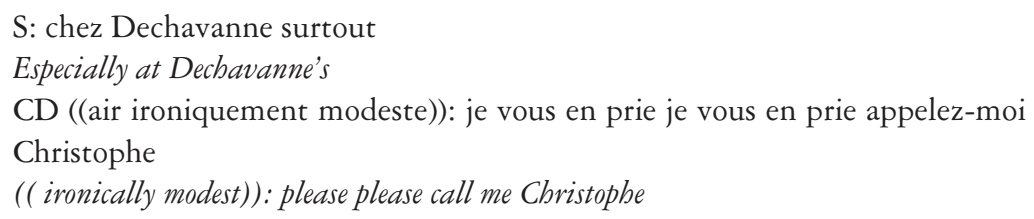

Sandra chooses to address the host as Dechavanne, he corrects her gently by proposing "Christophe". Switching from Dechavanne to Christophe, our guest is obliged to alter her discursive strategy while "getting on the set", a crucial moment in her identity construction.

In the following example, a male participant accepts to play the game of the "just another participant":

(27) CD: appelez-moi Christophe

call me Christophe

Guest: je vous appellerai Christophe ... vu qu'on a à peu près le même âge à mon avis

I will since I think we are about the same age

$\mathrm{CD}$ : oui j'ai 25 ans moi-même ((P: rires))

Yes I'm 25 myself ((audience laughing))

In fact the guest in his early fourties apparently is of the same age as Dechavanne so his idea about sharing age seems legitimate. Nevertheless, the mocking remark of Dechavanne is "punishing" him for making the wrong choice.

Although we are confronted here with two opposite cases, it must be clear that whatever option the guest takes, selecting Dechavanne or Christophe, his choice will never be the right one.

Not only does the host determine his own identity, he also holds a firm grip on the identity construction of his guests.

Two examples:

(28) CD: bonjour présentez-vous monsieur good evening introduce yourself sir

Guest: je suis Jean-Paul Jean-Paul Bidot euh

I am Jean-Paul Jean-Paul Bidot euh

$\mathrm{CD}$ : oui . enchanté monsieur Bidot

Yes . pleased to meet you mister Bidot 
"Monsieur Bidot" introduces himself as "Jean-Paul" realizing the use of first name is a somewhat tacit rule in greeting sequences. So the host being "Christophe", the guest can only be "Jean-Paul". Not with a host that's constantly changing identities and Mr. Bidot is forced into a less relaxed style of interaction than the one Dechavanne suggested through other interventions.

(29) CD: monsieur le maire

mister mayor

Guest: appelez appelez-moi Jean-Claude

Call me Jean-Claude

CD: monsieur Jean-Claude

Mister Jean-Claude

Not giving in to the mayor's proposal - a mayor needs to be treated with some deference -, Dechavanne makes a somewhat ironic compromise (mister+first name) correcting the guest for "forgetting" his status. Caught between "Jean-Paul" and "monsieur le maire", our guest finds himself suspended in a hybrid and unconfortable position for building up his public image ${ }^{13}$.

Pulling on the strings of identity construction proves to be another beneficiary strategy for keeping the host's control over the ongoing forum. Remembering the "you can say whatever you want and whenever you want" discourse of our host, his management reveals to be a rather cynical enterprise meant to preserve Dechavanne's fame and glory at the expense of his guests. But is there more to be expected from a very diverting talk show?

\section{Conclusion}

We will conclude with an anecdote. We have observed that Dechavanne's talk show is indebted to the model of the assembly that as

\footnotetext{
13 Terms of address are undoubtedly the most unambiguous indicators on taxemic level. However, contributing heavily to the public image one wants to create (on the representation of the self, cf. E. Goffman 1973) or to the "face" one wants to preserve (cf. the concept of Face Treathening Acts in Brown\&Levinson 1989), terms of address have to be carefully interpreted.
} 
a rule is the place of performing speech, operating symbiosis between speech and act. Yet we find in the last broadcast of this series an exchange that seems to be a confession with regard to this aspect. "Du fer c'est bien" (iron is good), observes one of the participants. F E R referring to the title of course, and not to the homonym "faire" (to do). This is the reply of the host, who is reluctant to accept the compliment and makes a pun: "le fer c'est bien enfin le dire c'est mieux" (doing it is all right but saying it is much better). Let me rephrase this as "you are on television, not in the assembly and what is said here has no consequences whatsoever".

\section{E-mail: Ludwina.VanSon@ufsia.ac.be \\ Recebido em julho de 2002 Aprovado em fevereiro de 2004}

\section{REFERENCES}

Bourdieu, P. 1996. Sur la télévision suivi de L'emprise du journalisme. Paris: Liber.

Breton, P. \& Proulx, S. 1990. L'explosion de la communication. Paris: La Découverte.

Brown, P. \& Levinson S. 1989. Politeness: some universals in language usage. Cambridge: Cambridge University Press.

Goffman, E. 1973. La mise en scène de la vie quotidienne (2 vol.). Paris: Minuit. 1981. Forms of talk. Philadelphia: University of Pennsylvania Press.

Hodge, R. \& Kress, G. 1993. Language as Ideology. London: Routledge.

ILIE, C. 1999. Question-response argumentation in talk shows. Journal of Pragmatics 31. Amsterdam: Elsevier.

Kerbrat-Orecchioni, C. 1990. Les interactions verbales. Tome I. Paris: A. Colin. 1992. Les interactions verbales. Tome II. Paris: A. Colin.

LYOTARD, J.-F. 1986. Le postmodernisme expliqué aux enfants: correspondance 1982-1985. Paris: Minuit.

Penz, H. 1996. Language and Control in American TV Talk Shows. An analysis of Linguistic Strategies. Tübingen: Gunter Narr Verlag.

Poirot-Delpech, B. Il faut qu'on parle. Le Monde, 19/6/2001.

Timberg, B. 1994. The Unspoken Rules of Talk Television. In: Newcomb, H. Television. The Critical View. New York/Oxford: Oxford University Press.

Wolton, D. 1997. Penser la communication. Paris: Flammarion. 